\title{
INFLUENCE OF DOMESTIC LIVESTOCK GRAZING ON AMERICAN PIKA (OCHOTONA PRINCEPS) HAYPILING BEHAVIOR IN THE EASTERN SIERRA NEVADA AND GREAT BASIN
}

\author{
Constance I. Millar ${ }^{1}$
}

\begin{abstract}
In a pilot study, I observed a relationship between domestic livestock grazing and location of American pika (Ochotona princeps) haypiles in the eastern Sierra Nevada and several Great Basin mountain ranges. Where vegetation communities adjacent to talus bases (forefields) were grazed, mean distance from the talus borders to the closest fresh haypiles was $30.1 \mathrm{~m}(\mathrm{SD}=18.9 \mathrm{~m}, n=27)$, and haypiles were found only high in the talus. In ungrazed forefields, mean distance was $1.8 \mathrm{~m}(\mathrm{SD}=0.9 \mathrm{~m}, n=57)$, and haypiles were found along the low-elevation talus-vegetation border. Where grazing was active, haypiles consistently contained vegetation gathered from plants growing within the talus. Talus vegetation appeared to be of lower diversity and the plant species of lower nutritional value than forefield plants. This difference, if real, would compromise quality of forage for summer browsing and winter havpile storage. This condition, combined with potentially less favorable summer and winter thermal conditions of upper talus locations relative to lower talus borders, suggests that grazing might be a factor compromising population conditions and status of pikas. Recent studies have reported higher extirpation rates of pika populations in Great Basin ranges (primarily in Nevada) than in adjacent regions. Because domestic livestock grazing is widely permitted on public lands throughout pika habitat in the Great Basin but not permitted (or much more restricted) in pika habitat of the Sierra Nevada, California, grazing effects might be contributing to observed regional differences in viability of pikas.
\end{abstract}

RESUMEN._-En un estudio preliminar, observé la relación entre el pastoreo por ganado doméstico y la ubicación de las reservas de comida de la pica americana (Ochotona princeps) en el este de la Sierra Nevada y de varias cordilleras de la Gran Cuenca. En las zonas de vegetación adyacentes a bases del talud (antepaís) que han sido pastoreadas, la distancia promedio de los límites del talud a las reservas de alimento fresco más cercanas fue de $30.1 \mathrm{~m}(\mathrm{DE}=18.9 \mathrm{~m}, n=27)$; a su vez, sólo se encontraron tales reservas en las partes altas del talud. En el antepaís que no ha sido pastoreado, la distancia promedio fue de $1.8 \mathrm{~m}(\mathrm{DE}=0.9 \mathrm{~m}, n=57)$, y se encontraron reservas de alimento a lo largo del límite entre la parte baja del talud y la vegetación. En lugares donde el pastoreo ha sido activo, las reservas de alimento estaban compuestas consistentemente de vegetación recolectada de las plantas que crecían dentro del talud. Esta vegetación del talud pareció ser de menor diversidad y las especies de plantas de menor valor nutricional en comparación con la plantas del antepaís. Si esta diferencia es real, comprometería la calidad del forraje para el ramoneo del verano y el almacenamiento de alimento para el invierno. Esta condición, combinada con las condiciones térmicas potencialmente menos favorables del verano e invierno en las zonas altas del talud en comparación con los extremos inferiores del talud, sugieren que el pastoreo podría ser un factor que esté comprometiendo las condiciones de la población y el estatus de las picas. Hay estudios recientes que han observado una extirpación mayor de las poblaciones de picas en las cordilleras de la Gran Cuenca (principalmente en Nevada) en comparación con regiones adyacentes. Debido a que el pastoreo por ganado doméstico se permite en muchos terrenos públicos a lo largo del hábitat de la pica en la Gran Cuenca, pero no se permite (o está mucho más restringido) en el hábitat de la pica en la Sierra Nevada, California, los efectos del pastoreo podrían estar contribuyendo a las diferencias regionales observadas en la viabilidad de las picas.

American pikas (Ochotona princeps) are small montane mammals related to rabbits (order Lagomorpha) and are widely distributed across mountains of western North America (Smith and Weston 1990). They favor talus and other rocky habitats, defend solitary territories, exhibit classic metapopulation dynamics, and they do not hibernate (Smith and Gilpin 1997). Poor thermoregulation and low lethal maximum temperatures (Smith 1974a, Yang 1990, Kosaka et al. 1999) have prompted concern for the vulnerability of pikas to climate change, and endangered species listing has been requested repeatedly for pikas, despite contradictory evidence regarding the species' status. Resurveys of early 20th-century locations (Beever 2002, Beever et al. 2003, 2008, 2010, 2011, Moritz et al. 2008) and surveys of existing populations (Hafner 1994, Simpson 2009, Millar and Westfall 2010, Rodhouse et al. 2010) indicate variability in the current geographic and elevational distribution of pikas relative to their historic range. In ranges with extensive habitat, such as the Sierra Nevada, Cascade

${ }^{1}$ USDA Forest Service, Pacific Southwest Research Station, 800 Buchanan St., WAB, Albany, CA 94710. E-mail: cmillar@fs.fed.us 
Mountains, and Rocky Mountains, pikas persist across wide elevation bands, exploiting diverse talus landforms and saturating available habitat. By contrast, populations in Great Basin mountain ranges appear to have higher extirpation rates, lower abundances, and higher percentages of unoccupied habitat (Beever et al. 2003, 2008, 2011, Millar and Westfall 2010).

Attribution of these differences remains uncertain, and several hypotheses have been proposed to explain the status of pikas in the Great Basin. Multivariate analyses indicate that climate change, expressed through chronic summer warming and/or acute winter cold stress, is the dominant factor influencing observed declines in the Great Basin (Beever et al. 2003, 2010, 2011, Rodhouse et al. 2010, Wilkening et al. 2011); however, island biogeographic considerations could also explain these patterns. Habitat within Great Basin ranges is scattered and disjunct, and mountain ranges are isolated, greatly restricting dispersal within and especially between ranges. This situation, coupled with the metapopulation dynamics exhibited by pika populations, predicts lower habitat occupancy within ranges and lower recolonization rates across ranges for regions like the Great Basin relative to extensive cordillera (Smith 1974b, Hafner and Sullivan 1995, Gorrell et al. 2005, Millar and Westfall 2010). Both climatic and island biogeographic hypotheses are supported by paleoecological evidence from the Great Basin, which documents extirpations of pikas from ranges without recolonization during the Holocene and shows that extirpations correlate with low elevations and warm temperatures (Hafner 1993, Grayson 2005).

Given questions about the vulnerability of pikas to changing climates, focus on Great Basin populations is important. I offer preliminary observations to suggest another factor that might influence the status of pikas in Great Basin ranges: grazing by domestic livestock on vegetation communities adjacent to pika talus bases (forefields). Grazing can remove preferred forage, driving pikas to poor-quality habitat high in talus fields and thereby impacting their population health. A difference in range management policies exists between the primary public agency units that administer pika habitat in this region. Thus, a grazing effect, if present, could be pervasive through much of the Great Basin mountain regions. In Nevada and a small portion of
California, a significant extent of pika habitat is administered by the USDA Forest Service (Humboldt-Toiyabe National Forest [HTNF]) or the Bureau of Land Management. These administrative units maintain active domestic livestock allotments throughout many mountainous regions, including vegetation communities at elevations up to and including alpine habitat. By contrast, most public agencies administering land in the Sierra Nevada (except a piece managed by the HTNF) currently exclude grazing from most mid- to high-elevation regions that support pikas (Michele Slaton, Inyo National Forest, personal communication).

Under typical conditions, pika territories average $<50 \mathrm{~m}$ in diameter and pikas preferentially locate haypiles along lower talus borders adjacent to meadows, and grass- and shrublands that support choice forage (Smith and Ivins 1984, Smith and Weston 1990). Although pikas are generalized herbivores, they nonetheless select high-value forage species depending on season and availability (Huntly et al. 1986). During warm seasons, pikas forage daily in talus forefields within a few meters of the talus border. By mid- to late summer, they begin to collect vegetation for winter consumption. This vegetation comes from the same forefields but is often a different species mix than the forage consumed directly. Pikas stockpile this vegetation in large hoards ("haypiles") under boulders within the talus field, usually one to several per territory (Millar and Zwickel 1972). Haypile vegetation is eaten during winter when fresh forage is unavailable. Haypile plants are selected on the basis of high nutritional and caloric content, as well as capacity for preservation during many months in cold, wet conditions (Dearing 1997). Haypiles are often located close to $(<6 \mathrm{~m}$ from) the talus/vegetation interface (Millar and Zwickel 1972). This short distance minimizes the time and risk for pikas traveling from haypile to forefield. Pikas augment their haypiles, especially in late winter or early spring, by running either over snow to collect foliage from conifer trees whose branches drape onto the snowpack or through snow tunnels to collect vegetation along the talus borders. Location of haypiles near the borders of talus fields thus appears critical for year-round access to abundant and high-quality forage.

In addition to their proximity to forage, lower locations within a talus field appear to have 
more favorable thermal regimes for pikas than higher intratalus locations, irrespective of the elevation of the talus field. Studies of periglacial blockfields and preliminary studies of pika talus indicate that the coolest warm-season temperatures are within the talus matrix (below surface rocks) at the talus base (Harris and Pedersen 1998, Delaloye and Lambiel 2005, Juliussen and Humlum 2008, Millar and Westfall 2008, 2010, unpublished data). This temperature pattern appears to be related not only to external cold-air drainage but also to intratalus ventilation processes that are partially decoupled from external atmospheric conditions. Talus bases also maintain greater snowcover in winter than locations higher in talus fields (Harris and Pedersen 1998); thus haypiles and animals that are near the talus base are insulated and less exposed to cold winter external air temperatures.

In mid-September 2010, I first observed unusual pika behavior in the canyons of Pine Creek, Toquima Range, Nevada. Pika calls, activity, and haypiles were not adjacent to talus borders as they typically are, rather they were consistently located high in the talus. Haypiles were found in close proximity to patches of Rubus idaeus ssp. strigosus (red raspberry), a small, thin-leafed shrub that grows sparsely in scattered clumps mostly midway up to high in talus fields. Haypiles were composed almost exclusively of this species. Red raspberry foliage and stems have low energy content, low nutritional value, and dense thorns - characteristics that contribute to the species' rating as poor forage for wildlife and livestock (USDA Forest Service 2010). Moreover, nutritional quality of red raspberry leaves and stems declines as the growing season progresses (USDA Forest Service 2010), further reducing their value at the time when pikas collect vegetation for haypiles. Whether red raspberry foliage in haypiles improves or further declines in nutritive value over the winter is unknown.

Compared to talus vegetation, forefield plant communities in the Toquima Range were, as is widely the case elsewhere, highly productive, densely vegetated, mostly mesic meadow types containing a variety of forage species with high nutritional and energetic content for wildlife and livestock. While these meadows would typically be locations for pika foraging, during the time I visited in mid-September 2010, the im- pact of grazing on forefield vegetation was evident and severe. Cattle were abundant in all drainages where I observed haypiles and pika activity, and forefield plant communities were heavily browsed with sign indicating that intensive grazing had occurred in the distant past as well as in recent years. Plant canopy heights in the forefields were cropped to less than approximately $5 \mathrm{~cm}$.

These observations prompted the hypothesis that livestock grazing in talus forefields removes biomass needed by pikas for daily forage and winter haypile collections. Without this vegetation in forefields, pikas are forced to seek forage elsewhere. Because pikas prefer talus habitat, and are at greater risk of predation off-talus, the most likely alternative would be for them to seek vegetation that grows within the talus field rather than moving farther off-talus in search of forage (Holmes 1991). By nature of the rocky environment, vegetation within talus is generally much lower in abundance, species diversity, and distribution than off-talus vegetation (Sawyer et al. 2009). Thus, pikas foraging within talus would likely encounter less vegetation and possibly (as in the case of red raspberry) poorer-quality vegetation than pikas foraging in ungrazed forefields. Lower quantities and quality of vegetation could compromise summer and winter forage and health conditions for pikas. Further, by being forced higher in talus fields, pikas would be active in summer in locations that appear to have warmer intratalus thermal regimes, and winter haypiles would be in talus locations that are more exposed to cold surface air (less insulating snowpack).

On the basis of this hypothesis, I began a pilot study to observe pika behavior during September and October 2010 in locations where (1) grazing was present and forefield vegetation was grazed, and (2) grazing was not present in the forefield, regardless of whether livestock were present in the region (some talus locations are inaccessible to livestock). I visited 6 Great Basin mountain ranges and the eastern Sierra Nevada (located in the Great Basin but distinguished because of its extensive habitat) where pikas were active (Table 1 ). In 36 disjunct sampling areas (defined as separated by a minimum of $3 \mathrm{~km}$, the estimated maximum dispersal distance of individual pikas), I measured the distance (paced and rounded to 
TABLE 1. Distance from talus border to 84 pika haypiles and source of haypile plants in grazed and ungrazed regions of the Great Basin and Sierra Nevada ranges, California and Nevada. All but one grazed location (noted) were cattle allotments.

\begin{tabular}{|c|c|c|c|c|c|c|}
\hline Mountain range & State & $\begin{array}{l}\text { Sampling } \\
\text { areas }\end{array}$ & $\begin{array}{l}\text { Elevation } \\
\text { range }(m)\end{array}$ & Hayplies & $\begin{array}{l}\text { Mean distance }(\mathrm{SD}) \text {, } \\
\text { haypile to talus } \\
\text { edge }(\mathrm{m})\end{array}$ & $\begin{array}{l}\text { Haypile } \\
\text { source }^{b}\end{array}$ \\
\hline \multicolumn{7}{|l|}{ GRAZED } \\
\hline Sierra Nevada & CA & 4 & $2835-2940$ & 6 & $11.7(3.0)$ & $\mathrm{FF}$ \\
\hline Sweetwater & $\mathrm{CA}$ & 3 & $3080-3510$ & 5 & $51.8(23.1)$ & $\mathrm{T}$ \\
\hline Toiyabe & $\mathrm{NV}$ & 1 & $2985-3000$ & 3 & $28.0(4.4)$ & $\mathrm{T}$ \\
\hline Toquima & NV & 4 & $3140-3430$ & 10 & $32.5(15.1)$ & $\mathrm{T}$ \\
\hline White Mtns. & $\mathrm{CA}, \mathrm{NV}$ & 2 & $2490-3020$ & 3 & $23.0(13.7)$ & $\mathrm{T}$ \\
\hline Total grazed & & 14 & & 27 & $30.1(18.9)$ & \\
\hline \multicolumn{7}{|l|}{ UNGRAZED } \\
\hline Bodie Hills & CA & 2 & $2520-2680$ & 9 & $1.8(0.7)$ & $\mathrm{FF}$ \\
\hline Sierra Nevada & CA & 7 & $2800-3290$ & 21 & $2.4(0.5)$ & $\mathrm{FF}$ \\
\hline Sweetwater & CA & 3 & $3100-3290$ & 3 & $3.1(1.1)$ & $\mathrm{FF}$ \\
\hline Wassuk & $\mathrm{NV}$ & 5 & $3000-3390$ & 12 & $1.5(1.1)$ & $\mathrm{FF}$ \\
\hline White Mtns. & $\mathrm{CA}, \mathrm{NV}$ & 5 & $3025-3525$ & 12 & $1.4(0.9)$ & $\mathrm{FF}$ \\
\hline Total ungrazed & & 22 & & 57 & $1.8(0.9)$ & \\
\hline TOTAL & & 36 & & 84 & & \\
\hline
\end{tabular}

Sierra Nevada: Burt Canyon, Molybdenite Canyon, Green Creek Canyon, Virginia Canyon; Sweetwater: Belfort, Frying Pan Canyon, Mt. Wheeler, Mt. Patterson, Lobdell Lake; Toiyabe: N and S Forks Twin River Canyon; Toquima: S and Middle Forks Pine Creek, Mt. Jefferson Plateau; White Mtns.: Crooked Creek Canyon, Wyman Canyon, Mt. Barcroft, Cottonwood Canyon, Trail Canyon; Bodie Hills: Bodie State Historic Park, Masonic; Wassuk: Cottonwood Canyons, Dutch Creek Canyon, Rose Creek Canyon, Big Indian Mtn.

$\mathrm{b}_{\mathrm{T}}=$ talus plant species only; $\mathrm{FF}=$ forefield and talus plant species.

cOne region contained a sheep allotment.

nearest $0.5 \mathrm{~m}$ ) from the talus/vegetation border to the nearest fresh haypile. These mountain ranges span a wide range of parent substrate material and vegetation communities; aside from impacts of cattle, there were no systematic differences in ecologic, geographic, climatic, or physical/environmental conditions between grazed and ungrazed sampling areas. I recorded haypiles only when they were separated by at least $50 \mathrm{~m}$. Also, in each talus, I recorded only the visible haypile nearest the low-elevation talus border (adjacent to the toe of the talus field), although others might have occurred above this. The reason for this protocol was that under normal conditions, locations along the talus border are where pika haypiles are most often located (Smith and Weston 1990). I recorded large mammal grazing activity in forefield plant communities and noted whether haypiles consisted of species growing in talus or species occurring predominantly or exclusively on forefields.

In total I observed 84 haypiles. Mean distance of haypiles to talus borders for grazed forefields was $30.1 \mathrm{~m} \mathrm{(SD}=18.9 \mathrm{~m}, n=27)$, which was significantly greater than the mean of $1.8 \mathrm{~m} \mathrm{(SD}=0.9 \mathrm{~m}, n=57)$ for ungrazed situations $(t=7.8, \mathrm{df}=26, P<0.0001$; Table 1$)$. This relationship occurred consistently across mountain ranges and also within ranges where grazing was permitted and where comparisons were made between both grazed forefields and those where environmental conditions precluded livestock from forefields. In almost all cases where haypiles were distant from talus borders, the dominant vegetation in haypiles was derived from species that grew within the talus fields, whereas haypiles near talus borders were made of forefield and within-talus vegetation.

Observations from this pilot study are preliminary, but they suggest a possible factor impacting the status of pikas in Great Basin locations where forefields are heavily grazed. Lack of abundant, diverse, and nutritional forage for direct and stored consumption might lower overall fitness of pikas. Similarly, lack of adequate forefield vegetation appears to force pikas to move high in the talus to find alternative food, exposing them to potentially less favorable thermal conditions in summer as well as in winter. Other researchers have suggested a possible role of livestock grazing in determining pika forage availability (Huntly et al. 1986). Beever et al. (2003) tested the effect of grazing on pika extirpation in the Great Basin, but their results were inconclusive, possibly because grazing was recorded at the mountain-range level rather than by individual talus fields.

Because policy differences exist among the public agencies that administer land in this 
region, grazing might be an important, if little studied, factor affecting persistence of pikas in the Great Basin relative to other regions. That grazing impacts might exacerbate other factors affecting pika viability in Great Basin ranges (e.g., climate change, biogeographic challenges) suggests that this hypothesis warrants additional research, a direction we are now pursuing.

I thank Drs. Chris Fettig, Andrew Smith, David Tart, and Robert Westfall for review of the early manuscript, and Drs. Erik Beever and Mark Belk (WNAN editor-in-chief) for reviews of the submitted manuscript.

\section{Literature Cited}

BeEver, E.A. 2002. Persistence of pikas in two low-elevation national monuments in the western United States. Park Science 21:23-29.

Beever, E.A., P.E. Brussard, and J. Berger. 2003. Patterns of extirpation among isolated populations of pikas (Ochotona princeps) in the Great Basin. Journal of Mammalogy 84:37-54.

Beever, E.A., C. Ray, P.W. Mote, and J.L. Wilkening. 2010. Testing alternative models of climate-mediated extirpations. Ecological Applications 20:164-178.

Beever, E.A., C. Ray, J.L. Wilkening, P.F. Brussard, and P.W. Mote. 2011. Contemporary climate change alters the pace and drivers of extinction. Global Change Biogeography. doi: 10.1111/j.1365-2486.2010.02389.x

Beever, E.A., J.L. Wilkening, D.E. McIvor, S.S. Weber, AND P.F. BRussaRD. 2008. American pikas (Ochotona princeps) in northwestern Nevada: a newly discovered population at a low-elevation site. Western North American Naturalist 68:8-14.

DEARING, M.D. 1997. The manipulation of plant toxins by a food-hoarding herbivore, Ochotona princeps. Ecology 78:774-781.

Delaloye, R., AND C. LAMBiEL. 2005. Evidence of winter ascending air circulation throughout talus slopes and rock glaciers situated in the lower belt of alpine discontinuous permafrost (Swiss Alps). Norsk Geografisk Tidsskrift 59:194-203.

Gorrell, J.V., M.E. Anderson, K.D. Bunnell, M.F. Canning, A.G. Clark, D.E. Dolsen, and F.P. Howe. 2005. Utah Comprehensive Wildlife Conservation Strategy [CWCS]. Utah Division of Wildlife Resources, Salt Lake City, UT. Available from: http://wildlife.utah .gov/cwcs/10-01-21 utah cwes strategy.pdf

Grayson, D.K. 2005. A brief history of Great Basin pikas. Journal of Biogeography 32:2103-2111.

HaFnER, D.J. 1993. North American pika (Ochotona princeps) as a Late Quaternary biogeographic indicator species. Quaternary Research 39:373-380.

1994. Pikas and permafrost: Post-Wisconsin historical zoogeography of Ochotona in the southern Rocky Mountains, USA. Arctic and Alpine Research 26:375-382

Hafner, D.J., and R.M. Sullivan. 1995. Historical and ecological biogeography of Nearctic pikas (Lagomorpha: Ochotonidae). Journal of Mammalogy 76:302-321.
Harris, S.A., AND D.E. Pedersen. 1998. Thermal regimes beneath coarse blocky materials. Permafrost and Periglacial Processes 9:107-120.

Holmes, W.G. 1991. Predator risk affects foraging behavior of pikas: observational and experimental evidence. Animal Behaviour 42:111-119.

Huntly, N.J., A.T. Smith, AND B.L. Ivins. 1986. Foraging behavior of the pika (Ochotona princeps), with comparisons of grazing versus haying. Journal of Mammalogy 67:139-148.

Juliussen, H., AND O. Humlum. 2008. Thermal regime of openwork block fields on the mountains Elgahogna and Solen, central-eastern Norway. Permafrost and Periglacial Processes 19:1-18.

Kosaka, M., G.-J. Yang, J.N.C. Piad, J.-B. Lee, Y. CaO, M. Yamauchi, E. Kaneda, T. Matsumota, N. Ohwatari, AND A. SAKAI. 1999. Thermobiological characteristics of pikas, rabbits and rats. Tropical Medicine 40: 157-163.

Millar, C.I., and R.D. WestFall. 2008. Rock glaciers and periglacial rock-ice features in the Sierra Nevada; classification, distribution, and climate relationships. Quaternary International 188:90-104.

2010 Distribution and climatic relationships of the American pika (Ochotona princeps) in the Sierra Nevada and western Great Basin, U.S.A.: periglacial landforms as refugia in warming climates. Arctic, Antarctic, and Alpine Research 42:76-88.

MillaR, J.S., AND F.C. ZwICKEL. 1972. Characteristics and ecological significance of hay piles of pikas. Mammalia 36:657-667.

Moritz, C., J.L. Patton, C.J. Conroy, J.L. Parra, G.C. WHITE, AND S.R. BEISSINGER. 2008. Impact of a century of climate change on small-mammal communities in Yosemite National Park, USA. Science 322:261-264.

Rodhouse, T.J., E.A. BeEver, L.K. Garrett, K.M. Irvine, M.R. Jeffress, M. MunTs, And C. Ray. 2010. Distribution of American pikas in a low-elevation lava landscape: conservation implications from the range periphery. Journal of Mammalogy 91:1287-1299.

Sawyer, J., T. Keeler-Wolf, And J. Evens. 2009. A manual of California vegetation. 2nd edition. California Native Plant Society.

Simpson, W.G. 2009. American pikas inhabit low-elevation sites outside the species' previously described bioclimatic envelope. Western North American Naturalist 69:243-250.

Smith, A.T. 1974a. Distribution and dispersal of pikas: influence of behavior and climate. Ecology 55: $1368-1376$.

. 1974b. The distribution and dispersal of pikas: consequences of insular population structure. Ecology 55:1112-1119.

SMith, A.T., AND M. GILPIN. 1997. Spatially correlated dynamics in a pika metapopulation. Pages 407-428 in I.A. Hanski and M.E. Gilpin, editors, Metapopulation biology: ecology, genetics, and evolution. Academic Press, New York, NY.

Smith, A.T., AND B.L. IvINs. 1984. Spatial relationships and social organization in adult pikas: a facultatively monogamous mammal. Zeitschrift für Tierpsychologie 66:289-308

Smith, A.T., AND M.L. Weston. 1990. Ochotona princeps. Mammalian Species 352:1-8.

USDA FOREST SERVICE. 2010. Fire Effects Information System [FEIS]. Fire Sciences Laboratory, Rocky 
Mountain Research Station, USDA Forest Service. Available from: http://www.fs.fed.us/database/feis/.

WiLKEning, J.L., C. RaY, E.A. BEEver, AND P.F. BRussard. 2011. Modeling contemporary range retraction in Great Basin pikas (Ochotona princeps) using data on microclimate and microhabitat. Quaternary International 25:77-88
YANG, G.J. 1990. Physiological characteristics of pika (Ochotona rufecens rufescens) as a weak heat tolerant animal. Tropical Medicine 32:129-140.

Received 7 December 2010 Accepted 18 May 2011 